Accepted refereed manuscript of:

Pierri Daunt AB \& Silva TSF (2019) Beyond the park and city dichotomy: Land use and land cover change in the northern coast of São Paulo (Brazil).

Landscape and Urban Planning, 189, pp. 352-361.

DOI: https://doi.org/10.1016/j.landurbplan.2019.05.003

(C) 2019, Elsevier. Licensed under the Creative Commons Attribution-

NonCommercial-NoDerivatives 4.0 International

http://creativecommons.org/licenses/by-nc-nd/4.0/ 


\section{Beyond the park and city dichotomy: Land use and land cover change in the northern 2coast of São Paulo (Brazil) \\ 3}

4Ana BeatrizPierri Daunt ${ }^{1}$, ThiagoSanna Freire Silva ${ }^{1,2}$

5

$6^{1}$ São Paulo State University (Unesp), Institute of Natural Sciences and Technology, Geography 7Department, Rio Claro, Brazil

8

$9^{2}$ Biological and Environmental Sciences, Faculty of Natural Sciences, University of Stirling, 10Stirling FK9 4LA, UK

11

12Abstract The natural and cultural landscapes of the Northern Coast of São Paulo State (Brazil) 13are threatened by increasing urban growth, as a result of inefficient land use management and 14fast population growth. Our work analysed land use/cover changes (LULCC) between 1985 and 152015 at 5 year intervals, to describe and understand the main processes and drivers of landscape 16change. LULCC were mapped using Landsat images and geographic object-based image analysis 17(GEOBIA), based on the Random Forests supervised algorithm. Over 30 years, we show a 18dichotomic trend for the two main land change trajectories: forest persistence and fast urban 19growth. We found only $8 \%$ of forest disturbance within the State Parks, while dense urban 20settlements grew $163 \%$ outside the park, mainly replacing rural uses. We estimate that all 21available land for human settlement may be occupied by 2030 as a result of this fast urban 22growth. Our study exemplifies a likely pattern of land use change for coastal regions, with fast 23urban growth driven by economic interests in transforming these regions into urban and touristic 24hubs, clashing with environmental policies for forest conservation and afforestation. The history 25of LULCC in the Northern Coast of São Paulo State has resulted in several land use conflicts in 26the present, especially when considering fast urban growth versus a very large proportion of 27areas where no human settlement is permitted. This complex combination of drivers has led to 28rural depopulation and decrease in small-scale agricultural uses, reducing the diversity and 29functionality of the studied landscape.

\section{1. Introduction}

Mankind has been shaping ecosystems and landscapes since the establishment of the first

34human settlements, but the speed, frequency and magnitude of landscape changes has increased 35mainly since the second half of the $20^{\text {th }}$ century; presently, more than $75 \%$ of Earth's ice-free 36land shows evidence of alteration as a result of human land use (Antrop, 2000; Ellis \& 37Ramankutty, 2008). Land use and land cover changes (LULCC) are difficult to predict and 38manage, and can result in severe consequences for climate, biodiversity, and ecosystem integrity 39and services, especially in the case of land build-up, which is usually irreversible (Elmqvist et 
40al., 2013, Verburg et al., 2015). Also, modern landscape changes are characterized by the loss of 41landscape diversity and changes in multifunctionality, mostly as a result of fast urbanization and 42urban population growth (Antrop, 2005), as well as by increased per capita land consumption 43(Inostroza, Baur \& Csaplovics, 2010). Land conversion from rural to urban uses can lead to 44several critical impacts on the quantity, quality and cost of food supply, and changes the complex 45relationship between people and the landscape though cultural heritage, feelings and values 46(Antrop, 2005; Bürgi, Verburg, Kuemmerle, \& Plieninger, 2017; De Groot, 2006; McNeely \& 47Scherr, 2009; Nassauer, 1995; Tuan, 1983).

48 In South America, almost $84 \%$ of the total population lives in cities, and predictions 49estimate that both urban population and urban areas will continue to increase rapidly in the next 50years (Inostroza et al., 2010; UN 2009). Such fast and intense urbanization in developing 51countries usually leads to vulnerability to extreme climate events, human settlement on socially 52and environmentally risky areas, pollution, deforestation, habitat and biodiversity loss, violence, 53and criminality (Elmqvst et al., 2013; Maricato, 2003).

54 In Brazilian coastal zones, fast urban growth is of large interest and concern in terms of 55LULCC and landscape changes. The region known as the "Northern Coast of São Paulo State" 56(NCSP) has a strong touristic vocation and has shown one of the highest annual rates of 57population growth in the country (1.6\% from 2015 to 2016), twice as large as the state average 58(FSEADE, 2016) and caused mostly by migration from other regions and from local rural areas 59to urban centers (Carmo, Marques, \& Miranda, 2012; Rosemback et al., 2017). Economical 60interests in infrastructure development and expanding agricultural frontiers have been discussed 61as the main drivers of urban sprawl and deforestation in tropical ecosystems (Geist \& Lambin, 622002), and the natural and cultural landscapes of the Northern Coast of São Paulo State are 
63presently threatened by inefficient management of the increasing urban growth, leading to forest 64fragmentation and losses of biodiversity (Ab’Sáber, 1986; Dean, 1996; Ribeiro, Metzger, 65Camargo Martensen, Ponzoni, \& Hirota, 2009)

66 To control the impact of urban sprawl and to protect the Atlantic Forest, any form of 67human settlement is strictly forbidden in more than $80 \%$ of the NCSP territory, according to 68several environmental and land use policies and laws. Furthermore, long term LULCC data is not 69widely available for Brazil and most developing countries, thus independent studies quantifying 70LULCC are important to understand current occupation patterns and improve future urban 71planning and governance. Our work thus mapped land use and land cover changes between 1985 72to 2015, at five year intervals, to answer the following questions: 1) what are the main processes 73and trajectories of land use/cover change in the NCSP during the last 30 years? 2) What could be 74the main drivers of these changes? 3) What are the possible consequences of these changes on 75natural and cultural landscapes? 4) Have environmental legislation and regulations been effective 76in preserving forest cover?

\section{Methods}

$78 \quad 2.1$ Study area

79 The Northern Coast of São Paulo State is a recognized state administrative unit, mainly 80located along the Serra do Mar mountain range, and including four municipalities: 81Caraguatatuba, Ilhabela, São Sebastião and Ubatuba (Figure 1). The physical landscape of the 82NCSP is composed by three main physiographic compartments: the upland plateau between 800 83and $1300 \mathrm{~m}$ of elevation; the escarpments of the Serra do Mar mountain range, placed between 84the coastal plains and the uplands and characterized by steep slopes; and the coastal plains, with 85elevations below 20m and slopes of less than five degrees (Almeida \& Carneiro, 1998; Rossi \& 
86Queiroz Neto, 2001). Most human settlements occur on the coastal plain, but recent urban 87growth has pushed new settlements towards the steeper inland transitions. Considering the high 88annual rainfall volume (between 800 and $1200 \mathrm{~mm}$ ) and the very steep slopes, this region 89includes several high-risk areas for human settlement (Ab’Sáber, 2007; Rossi \& Queiroz Neto, 902001).

A

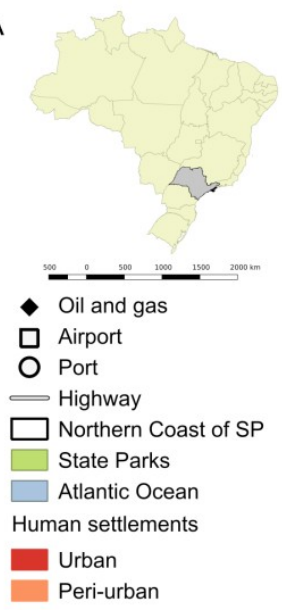

C

91

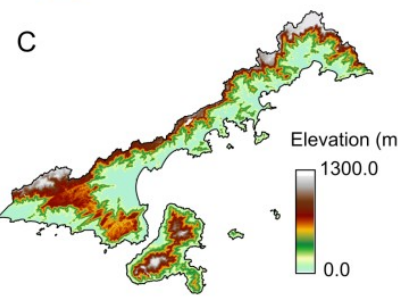

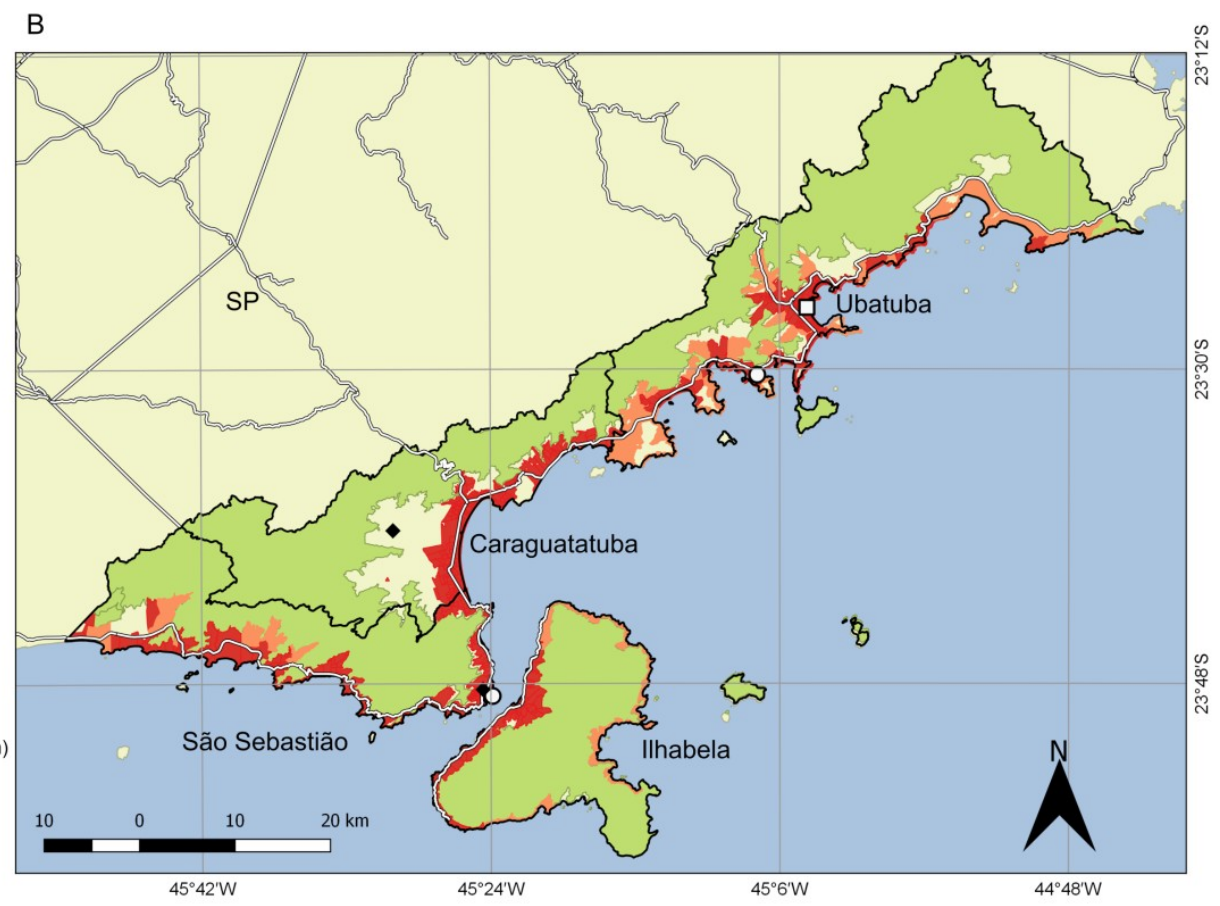

92Figure 1. A) Map of Brazil showing the location of São Paulo State (SP). B) Northern Coast of 93São Paulo State showing the location of state parks, main highways, oil and gas infrastructure, 94major ports and airports, and urban and peri-urban census sectors (IBGE, 2010). C) Digital 95Elevation Model (ALOS World3D, https://www.eorc.jaxa.jp/ALOS/en/aw3d30/index.htm). 96

97 The NCSP is located within the Atlantic Forest biome, which has one of the most diverse 98tropical biotas in the world (Mittermeier et al., 2004) and is among the biomes most threatened 99by human land use changes and urbanization process globally (Dean, 1996; Ribeiro et al., 2009). 100The Atlantic Forest was recognized as a biosphere reserve by UNESCO in 1991, and the Serra 101do Mar mountain range holds some of the largest and best preserved Atlantic Forest remnants 102(Fundação SOS Mata Atlântica; Instituto Nacional de Pesquisas Espaciais, 2016; Ribeiro et al., 
1032009). To protect the Atlantic Forest, several environmental and land use policies and laws have 104been passed during the late $20^{\text {th }}$ and early $21^{\text {st }}$ centuries, and three state parks were created in the 105NCSP in 1977 to support biodiversity conservation, environmental education and scientific 106research: “Serra do Mar”, “Ilhabela” and "Ilha Anchieta”. All state parks are classified as 107“integral protection” conservation units under the Brazilian Protected Areas legislation (Sistema 108Nacional de Unidades de Conservação - SNUC) (Brasil, 2000; São Paulo, 1977), thus any form 109of human settlement or land use is strictly forbidden. As an exception, the management plan of 110Serra do Mar State park has delimited a special restricted zone that allows sustainable use by 111native populations under park management regulations (São Paulo, 2006). Federal Law nº 11211428/2006 protects the Atlantic Forest biome and regulates the practices of deforestation, 113classifying transgressions as environmental crimes (Silva, Batistella \& Moran, 2006).

114 In addition to being an important biodiversity hotspot, the Northern Coast of São Paulo 115State also has unique historical and cultural characteristics, currently preserved by indigenous 116and traditional peoples (Ab’Sáber, 1986; São Paulo, 2006), such as the Tupi-Guarani nation and 117the Caiçara and Quilombola ethnicities, which have historically contributed to landscape 118sustainability and multifunctionality (Diegues, 2001; Antrop, 2005).

119 During the $20^{\text {th }}$ century, coffee producers and the industrial aristocracy "rediscovered" the 120coast of São Paulo for leisure and nature contemplation, occupying it with large secondary 121residences, and turning the region into a tourism hotspot (Campos, 2000; São Paulo, 2006). Also 122during the second half of the $20^{\text {th }}$ century, the tourism and oil industries demanded increased 123access to the NCSP, bringing the expansion of transportation networks and resulting in high rates 124of migration and population growth, with a resulting decrease in rural areas and urban expansion 125(Carmo et al., 2012; Cunha, 2003; Silva, 1975). 
$126 \quad 2.2$ Land use and land cover data

127 We acquired seven Landsat Collection 1 Higher-Level Surface Reflectance images 128(formerly known as Landsat Climatic Data Record images) distributed by the U.S. Geological 129Survey (USGS), covering the entire study area (path 76 row 220, WRS-2 reference system, 130https://earthexplorer.usgs.gov/). The series included six images acquired by the Landsat 5 131Thematic Mapper (TM) sensor, on 1985-07-27, 1990-07-09, 1995-05-04, 2000-01-10, 2005-0513215 and 2010-02-22, and one image from the Landsat 8 Operational Land Imager (OLI) sensor, 133from 2015-08-15. To avoid variations caused by vegetation phenology and changes in solar 134geometry, which could be detected as false cover changes (Kennedy, Yang, \& Cohen, 2010), we 135favoured images from the dry season of each year (May - August), with the exception of images 136from 2000 and 2010, which had extensive cloud cover during this period.

137 We applied a geographic object-based image analysis (GEOBIA) approach, which has 138become more popular for LULCC mapping during the last years (Blaschke, 2010). We chose this 139method as it enables mixed use classification and requires less workload for manual post140classification corrections. We segmented the images into objects with homogeneous spectral 141responses using the Shepherd segmentation algorithm implemented in the open source library 142“RSGISlib”, accessible through the Python programming language (Bunting \& Clewley, 2013). 143This algorithm requires three parameters: minimum object size in pixels (minPixls), maximum 144number of clusters (numClusters), and distance threshold between object pixels (disThres). We 145tested different parameter combinations, and chose the optimal combination based on visual 146assessment of the spatial coherence and spectral homogeneity of the resulting objects (Blaschke 147et al., 2014), corresponding to minPixls $=50$, numClusters $=120$ and disThres $=100$ (Appendix 148A). Mean spectral responses were then computed for each object across all multispectral Landsat 
149bands (1, 2, 3, 4, 5 and 7 for TM; 1, 2, 3, 4, 5, 6 and 7 for OLI) to be used as inputs for the 150classification algorithm (Blaschke, 2010).

151 We then classified land use and land cover at each imaged date using the Random Forests 152supervised algorithm (Breiman, 2001) implemented in the "Sci-Kit learn" Python library 153(Pedregosa et al., 2012). This algorithm is an ensemble learning method based on classification 154and regression trees built through randomization of the training data (Breiman, 2001). In our 155case, training data were the spectral responses of samples with known LULC categories (Table 1561). Homogeneous regions were manually selected as training samples, and delineated separately 157for each combination of LULC class and each imaged date, distributed as best as possible 158throughout the study area. The total area sampled for training each class depended on the relative 159proportion of the class within the scene, varying from $0.13 \mathrm{~km}^{2}$ for bare soil to $14.10 \mathrm{~km}^{2}$ for 160mature forest (Appendix A). Selection was based on visual interpretation of the images aided by 161visual comparison with high resolution datasets (see below).

162Table 1 - Land use and land cover classes used for mapping land cover changes in the Northern 163Coast of São Paulo State, Brazil, between 1985 and 2015, using Landsat historical data.

\begin{tabular}{l|l}
\hline Land use / land cover class & Description \\
\hline Mature forest & $\begin{array}{l}\text { Dense forest characterized by advanced successional stages and } \\
\text { comprised mainly by primary forest, or occasional old-growth } \\
\text { secondary forest. }\end{array}$ \\
\hline Regenerating forest & $\begin{array}{l}\text { Less dense forest at early to medium successional stages, } \\
\text { mostly comprised by regenerating secondary forest. }\end{array}$ \\
\hline Non-forest vegetation & $\begin{array}{l}\text { Native or exotic vegetation including pastures, grasslands and } \\
\text { agriculture. }\end{array}$ \\
\hline Bare soil and rock & $\begin{array}{l}\text { Exposed soil or rock surfaces lacking vegetation and buildings } \\
\text { and including sandy beaches and rocky shores. }\end{array}$ \\
\hline Peri-urban & $\begin{array}{l}\text { Mixed areas with lower population density and sparse } \\
\text { buildings, including a high diversity of rural uses, agroforestry, } \\
\text { and small forest fragments. }\end{array}$ \\
\hline
\end{tabular}




\begin{tabular}{l|l}
\hline Dense urban settlements & Dense built-up areas, mostly urban. \\
\hline Water & Free water surfaces. \\
\hline
\end{tabular}

164

165 The Sci-Kit learn implementation of Random Forests takes the following main 166parameters: "n_estimators", the number of trees used for decision, "bootstrap”, which is the 167randomization method, “out-of-bag”' (OOB), which estimates the classification error, and 168“class_weight”, which balances training samples. We optimized this parameter combination 169based on minimization of the OOB error, leading to " $n \_$estimators" = 500 and "class_weight” = 170“balanced”. The remaining parameters were kept at the default values (Appendices A) 171(Pedregosa et al., 2012). The automated classification was followed by careful visual inspection 172and manual correction of the land cover maps at the 1:25.000 scale, to improve map accuracy for 173all dates.

174 To aid image interpretation and support map validation and accuracy assessment, we 175obtained digital georeferenced colour aerial photographs from 2001 and 2010 at the 1:10.000 176scale, freely available at www.datageo.sp.gov. We also used the GoogleEarth ${ }^{\mathrm{TM}}$ platform to 177assess the accuracy of the most recent classification, based on Landsat 8 OLI. To generate the 178ground truth dataset, we randomly distributed 40 random points per LULC class for each date, 179which were then visually interpreted and classified based on the available high-resolution 180imagery. We then used these sets to build confusion matrices and derive global accuracy, per181class accuracy, the kappa index of agreement, and commission and omission errors (Congalton, 1821991).

183 Land use and land cover changes were quantified using map algebra, by comparing 184LULC maps in successive pairs. The area of each type of change was calculated using the 185"raster" package (Hijmans et al., 2016) of the R programming language (R Core Team, 2012), 
186which we then used to build the LULCC matrix. We then quantified the areal changes of each 187class in relation to the class area in the previous time step (PTS), both as absolute areas and as 188percentages. When relevant, we also determined changes in relation to the initial class area at the 189first time step (FTS), also in absolute and percentage values. We separately quantified absolute 190and PTS and FTS percent changes inside and outside State Parks, to better understand the 191different drivers on each type of land. For that, we used the official park limits provided by the 192Forestry Foundation of São Paulo. As the limits of Serra do Mar State Park were reviewed and 193expanded in 2010, changes prior to 2010 were quantified considering the original 1977 limits, 194and changes after 2010 considered the newly expanded limits.

\section{Results}

196 Land use and land cover maps for 2015, 2010 and 2000 had overall accuracies of 0.94, 1970.88, and 0.88, respectively, after manual revision and correction. Corresponding Kappa 198agreement indices were 0.92, 0.86, and 0.86. Considering that map classes, imaging sensor and 199mapping methods were the same for all years between 1985 and 2010, and based on the close 200similarity between 2010 and 2000 accuracies, we assumed similar expected accuracies $(0.88, \mathrm{\kappa}=$ 2010.86) for all remaining TM-based LULCC maps. The “dense urban settlement” class had the best 202Kappa index and the smallest errors, and the "peri-urban” and "regenerating forest” classes had 203the lowest Kappa indexes and the highest Omission and Commission errors (Table 2). Both 204“peri-urban” and "regenerating forest” classes comprised a more heterogeneous mixture of land 205cover elements than the remaining classes, which may explain the lower accuracies.

206Table 2. Kappa index of agreement and omission and commission errors for each LULC class 207from 2000, 2010 e 2015, after manual correction.

Classes

\begin{tabular}{|l|l|l|l|l|l|l|l|l}
\hline \multicolumn{3}{|c|}{ Kappa Index } & \multicolumn{3}{c|}{ Omission Error } & \multicolumn{3}{c}{ Commission Error } \\
\hline 2000 & 2010 & 2015 & 2000 & 2010 & 2015 & 2000 & 2010 & 2015 \\
\hline
\end{tabular}




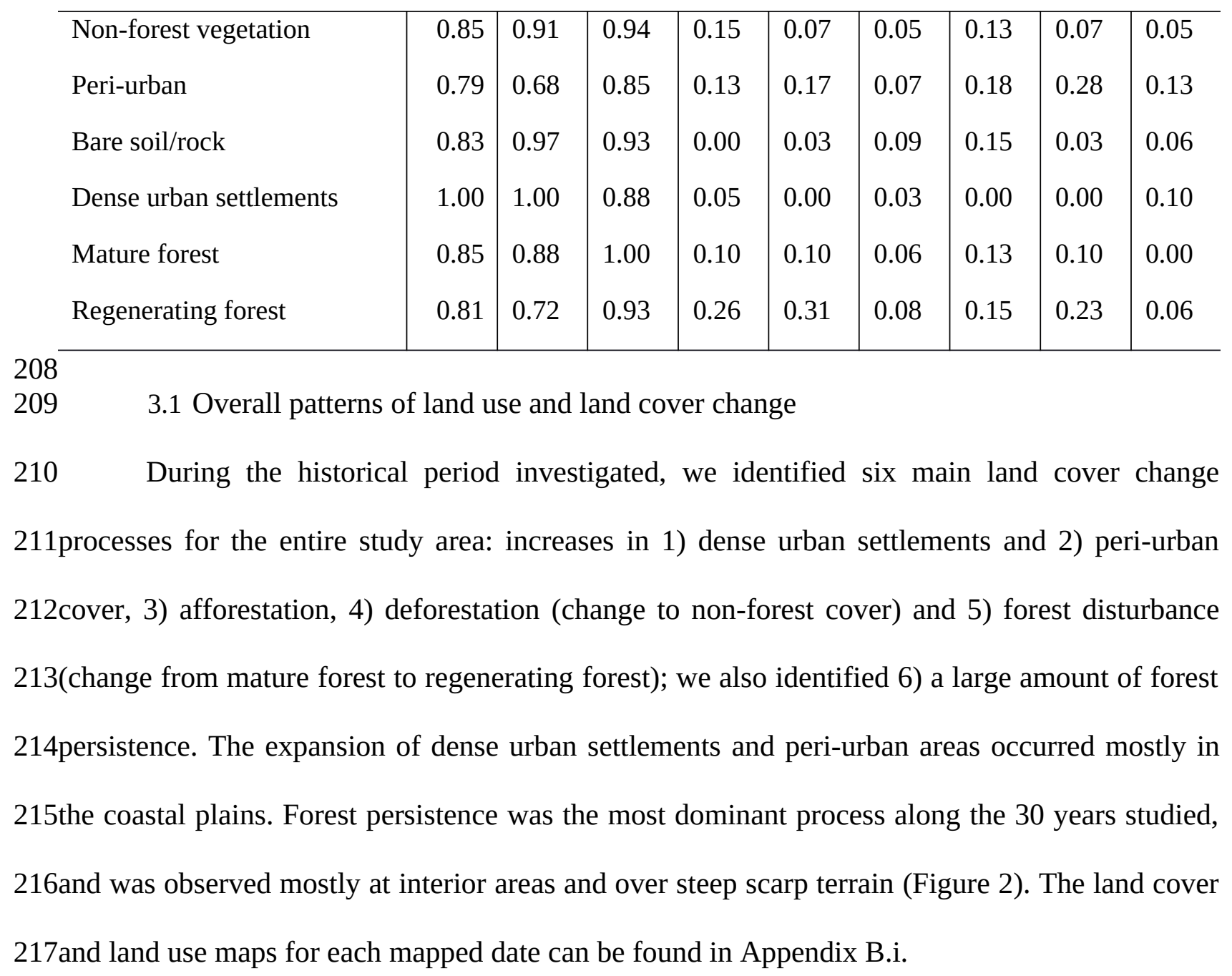




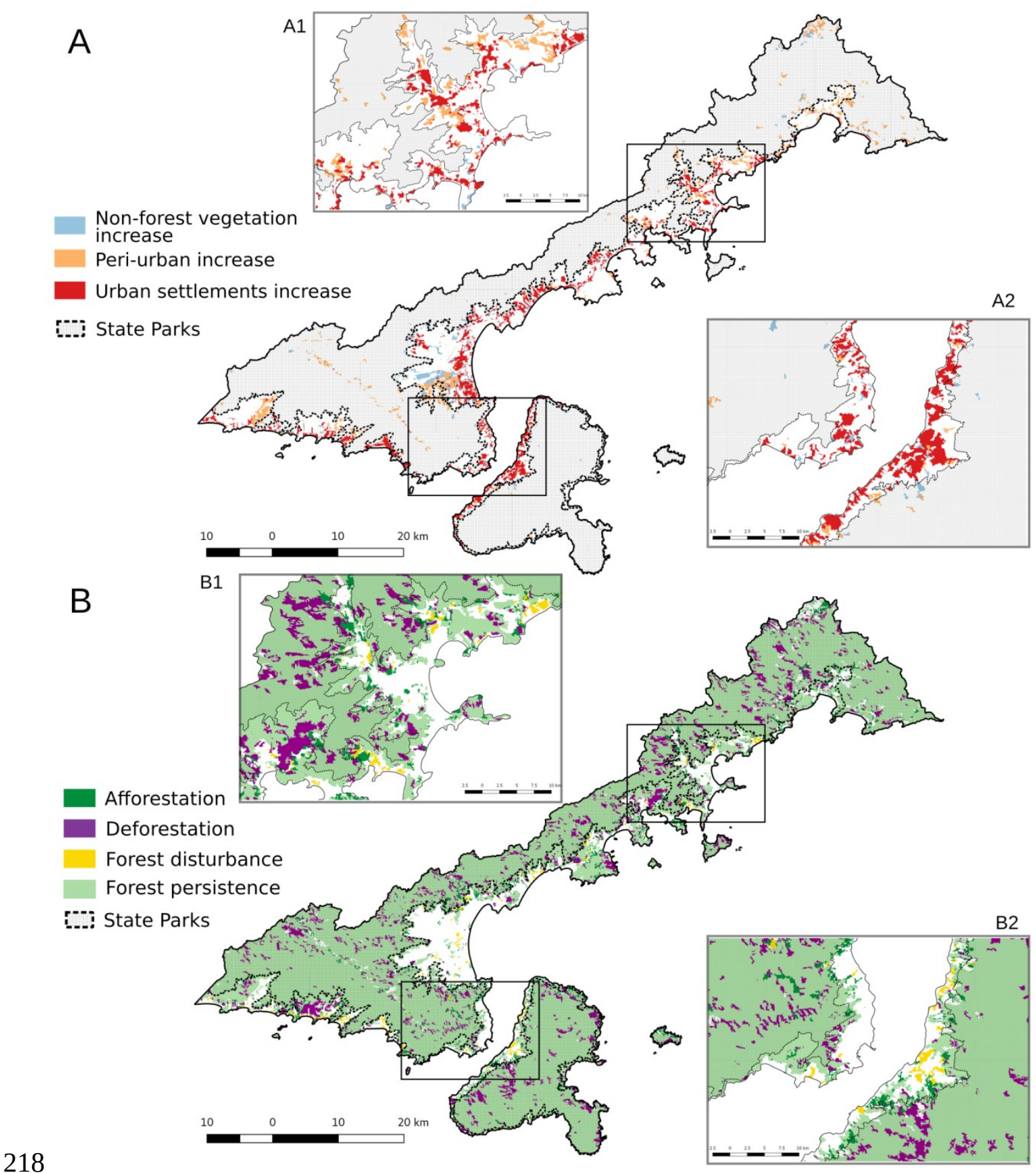

219Figure 2 Main land use and land cover change processes observed between 1985 and 2015. A) 220Non-forest vegetation, peri-urban and dense urban settlement increase; B) Forest dynamics: 221afforestation, deforestation, forest disturbance (primary to secondary forest), forest persistence.

222

223 Dense urban settlements increased from $46.3 \mathrm{~km}^{2}$ in 1985 to $123.8 \mathrm{~km}^{2}$ in 2015, an 224increase of $167 \%$ over 30 years, and the peri-urban cover increased $14 \mathrm{~km}^{2}$ (26.6\% of the class 225area in FTS). From the initial 1985 map, by 2015 dense urban areas replaced 25\% of non-forest 
226cover (33.7 km² FTS), 28.6\% of bare soil cover (5.6 km² FTS), 24.4\% of peri-urban cover (12.4 $227 \mathrm{~km}^{2}$ of urban intensification FTS) and $10.9 \%$ of mature forest (5.3 $\mathrm{km}^{2}$ of deforestation FTS) 228(Appendices B). Regenerating forests in 1985 were replaced by other LULC classes by 2015: 2298.1\% of non-forest vegetation $\left(17.5 \mathrm{~km}^{2}\right), 10.2 \%$ of peri-urban (22 $\left.\mathrm{km}^{2}\right)$, and $11 \%$ of dense urban 230settlement $\left(23 \mathrm{~km}^{2}\right)$.

$231 \quad 3.2$ Land use and land cover changes outside State Parks

232 From 1985 to 2015, dense urban settlements increased between almost all time steps, 233replacing mostly peri-urban uses and rural uses characterized by non-forest vegetation (Figure 2343), as well as a few natural cover areas, especially regenerating forests. Over the entire period, 235dense urban areas increased $74.5 \mathrm{~km}^{2}$ (162.4\% FTS) outside park limits, at an average annual 236rate of increase of 3.6\%. The largest expansion of urban settlements occurred between 1995 and 2372000 (almost 28 km², 43.6\% of PTS), followed by 1985 and 1990 (23\%, 11 km² PTS). Bare soil 238areas increased $12 \mathrm{~km}^{2}$ (94.3\% PTS) from 1990 to 1995 and then decreased almost 60\% between 2391995 and 2000, reflecting the frequent practice in the NCSP of clearing large areas to build urban 240settlements and private condominiums (urban sprawl, Appendix B). We also observed urban 241intensification in this period, shown by substitution of $9.6 \mathrm{~km}^{2}$ (23.6\% PTS) of peri-urban areas 242in 1995 by dense urban areas in 2000. The rate of dense urban expansion then started to decrease 243by the beginning of the $21^{\text {st }}$ century; 2005 to 2010 was the only interval without dense urban 244growth, and dense urban cover increased only 17.6 km² (17\% PTS) from 2010 to 2015.

245 


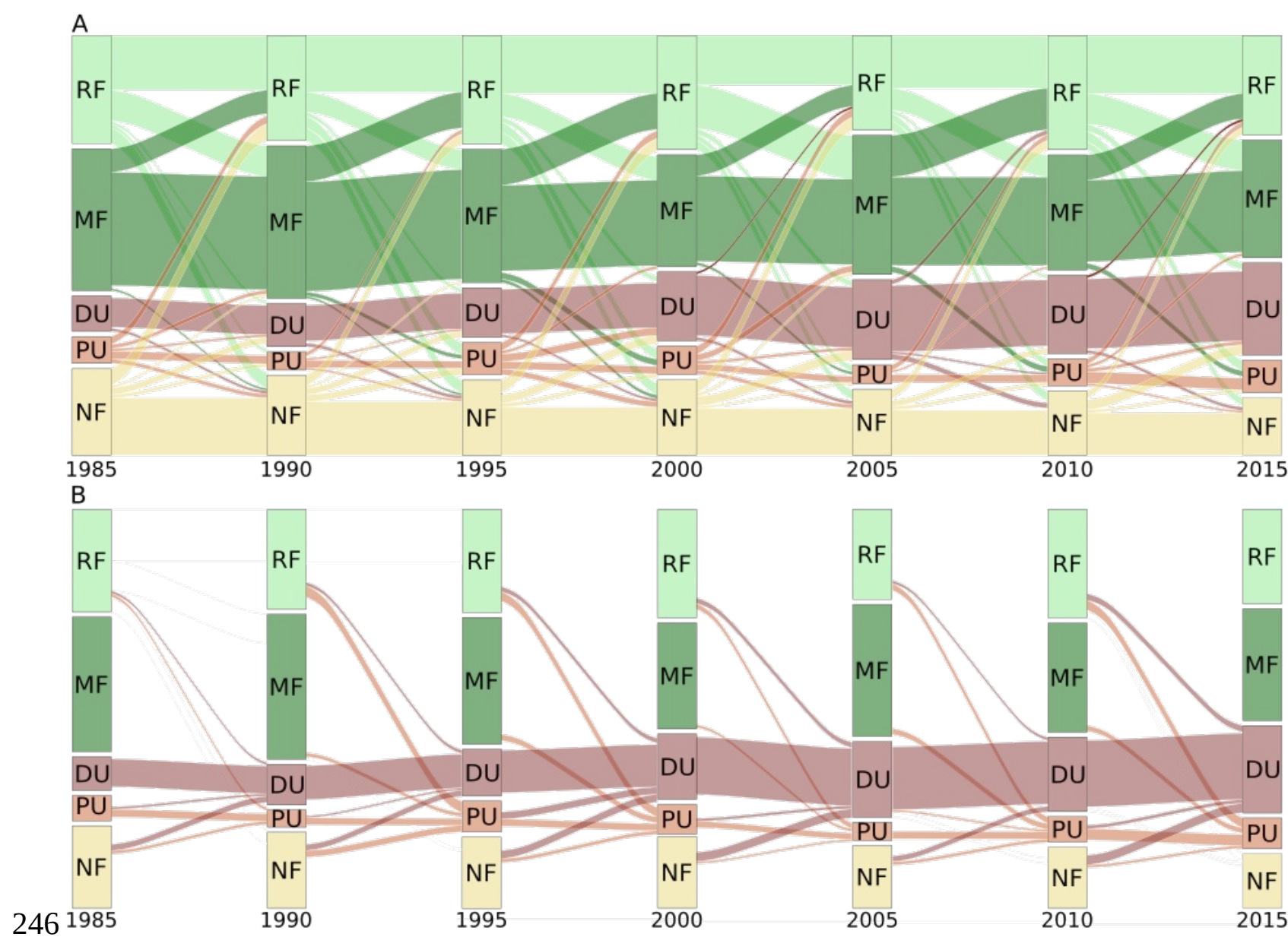

247Figure 3. Land use and land cover change trajectories for the areas of the Northern Coast of São 248Paulo outside park limits: A) All conversion types; B) land use / cover conversion to dense urban 249settlements and peri-urban areas. RF = Regenerating forest; MF = Mature forest; DU = Dense 250urban settlement; PU = Peri-urban; NF = Non-forest vegetation.

251

252 Peri-urban areas increased $6.7 \mathrm{~km}^{2}$ (19.5\% PTS) from 1985 to 2015, at an average annual 253rate of increase of 1.9\%. From 1985 to 1990 we quantified a peri-urban decrease of 33\% PTS (10 $254 \mathrm{~km}^{2}$ ) as a result of land abandonment and substitution by recovering forest and non-forest 255vegetation (land abandonment, Figure 4). We then observed high peri-urban growth between 2561990 and 1995 (73.8\% PTS, $17 \mathrm{~km}^{2}$ ), 2005 to 2010 (40\% PTS, $10 \mathrm{~km}^{2}$ ), and 2010-2015 (17\% 257PTS, $17.6 \mathrm{~km}^{2}$ ) (Figure 3B and Figure 4). This growth can be linked to new settlements (urban 258sprawl and a few new rural villages). Between 1995 and 2000, a peri-urban decrease of $4 \mathrm{~km}^{2}$ 259(10\% PTS) happened mostly due to urban intensification (Figure 4). Since dense urban 
260settlement and urban intensification occurred mostly within the flat coastal areas, our data 261suggests that the peri-urban areas have been shifted towards interior and steeper areas (Figure 2 262and 4).
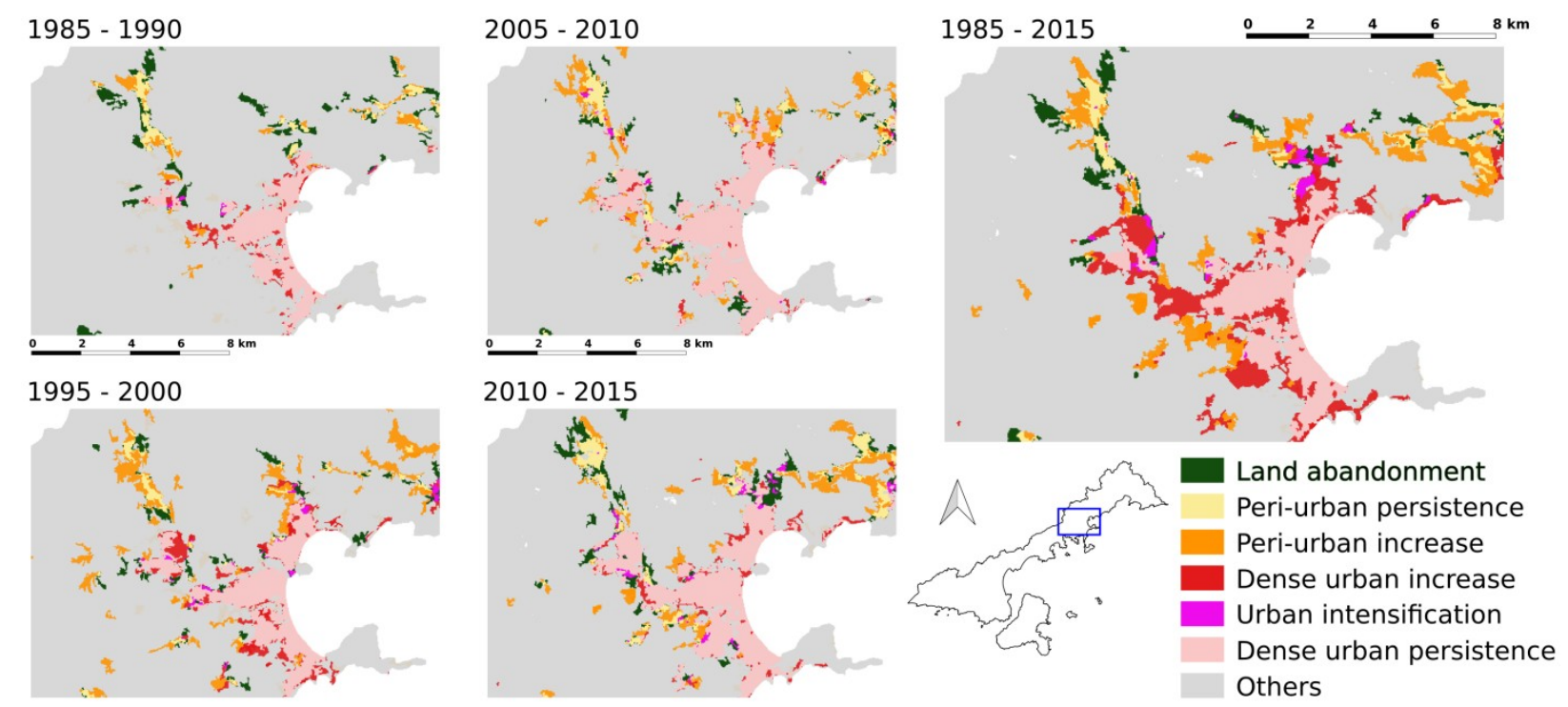

263Figure 4. Peri-urban and dense urban settlement dynamics: example from the central region of 264Ubatuba municipality. Land abandonment = peri-urban conversion to non-forest vegetation and 265regenerating forest; Peri-urban persistence $=$ peri-urban maintenance during the time step; Peri266urban increase $=$ conversion from any cover class to peri-urban; Dense urban increase $=$ 267conversion from any cover class to dense urban; Urban intensification $=$ conversion from peri268urban to dense urban, Urban persistence $=$ dense urban maintenance during the time step.

269

270 During the entire studied period, mature forest cover outside park limits decreased $16 \%$

271and regenerating forest decreased 8\% FTS due to deforestation. Mature forests present in 1985

272were converted into peri-urban areas (5.1\% FTS), dense urban settlements (3\% FTS) and 273regenerating forests (24\% FTS, i.e. forest disturbance) (Figure 3A). The 1995 to 2000 period had 274the largest loss of mature forest, $24 \mathrm{~km}^{2}$ (15\% PTS), while regenerating forests increased $11 \mathrm{~km}^{2}$ 275(7.9\% PTS) (Figure 3A). Forest cover outside park limits represented c.a. 50\% of the NCSP 276territory in 2015, considering both mature and regenerating forests (Figure 2 and Figure 3A). 277Even outside park limits, we could quantify high percentages of forest cover persistence, with $27864 \%$ of the forested area in 1985 remaining forested in 2015. We also observed afforestation, 
279resulting mostly from land abandonment, with a substitution of $20 \%$ of peri-urban and $15 \%$ of 280non-forest vegetation by regenerating forests from 1985 to 2015 (Appendices B).

281 At the municipal scale, all municipalities had LULCC patterns similar to the entire study 282area. During the 30 studied years, dense urban settlement increases were higher in percentage at 283Ilhabela (758.9\% FTS, followed by São Sebastião (174.4\% FTS), Ubatuba (146.5\% FTS) and 284Caraguatatuba (126.2\% FTS). Caraguatatuba lost 14.9\%, São Sebastião lost 24\%, and Ubatuba 285lost 15\% of mature forest, while Ilhabela gained 2.5\% from FTS. LULCC data by municipality 286can be found in the supplementary online material (Appendix B).

287

288 3.3 Land use and land cover changes within State Parks limits

289 The three state parks combined lost $100 \mathrm{~km}^{2}$ of mature forest (8\% FTS) from 1985 to 2902015, replaced mostly by regenerating forest and peri-urban cover. About $85 \%$ of total park area 291has persisted as mature forest (Figure 2). At the municipality scale, from 1985 to 2015, 292Caraguatatuba lost 7\% FTS, of mature forest, Ilhabela lost 8.5\% FTS, São Sebastião lost 3\% 293FTS, and Ubatuba lost 10.4\% FTS. The dense urban settlement areas increased from $1 \mathrm{~km}^{2}$ to 2.7 294km² from 1985 to 2015. Between 1985 and 1990, mature forest cover remained the same, and 295regenerating forest area increased almost $8 \mathrm{~km}^{2}$, replacing non-forest vegetation (afforestation). 296The peri-urban area increased $3 \mathrm{~km}^{2}$ and bare soil increased $2.6 \mathrm{~km}^{2}$, substituting both forest 297stages within park limits during 1990 and 1995. From 1995 to 2000, mature forest cover had a 298decrease of $40 \mathrm{~km}^{2}$ (5\% PTS), mostly substituted by regenerating forest, which increased $45 \mathrm{~km}^{2}$ 299(44.9\% PTS). Ilhabela State Park was the only park that did not lose mature forest cover between 3001995 and 2000. We quantified an increase of $2 \mathrm{~km}^{2}$ (12.6\% PTS) in new peri-urban settlements 301inside the parks between 2000 and 2005, and observed afforestation caused by changes from 
302regenerating to mature forest; mature forest increased $15 \mathrm{~km}^{2}$ while regenerating forest decreased $30360 \mathrm{~km}^{2}$. Regenerating forests replaced $107.6 \mathrm{~km}^{2}$ of mature forests between 2005 and 2010 . 304There were no notable changes within park areas between 2010 and 2015 (Appendix B).

305

3064. Discussion

307 4.1. Peri-urban and urban increases, land abandonment and rural decreases: why have $308 \quad$ people moved to cities?

309 The fast observed urban expansion in NCSP (167\% of dense urban and $26.6 \%$ of peri310urban from 1985 to 2015) can be linked to urban population growth, which went from 87,777 311inhabitants in 1980 to 223,914 in 2000 and 281,800 in 2010, as a result of migration to urban 312centers (Instituto Brasileiro de Geografia e Estatística, 1980, 2000, 2010). In 1970, 81\% of the 313censused population was classified as urban, increasing to $95 \%$ in 1980 and more than $98 \%$ in 3141991, 2000 and 2010 (Carmo et al., 2012; IBGE, 1970, 1980, 2000, 2010; Rosemback et al., 3152017). Inostroza et al (2010) have investigated different cities in South America and shown that 316population growth was a very important driver for urban expansion during the second half of the 31720th century, led mostly by emigration from rural areas to the cities. Over time, population 318increase has been losing its importance as a driving force for urbanization in Latin America, but 319cities have continued to grow fast, mostly as a result of changes in demographic structure and 320increases in the amount of per capita land consumption, influenced by economic changes (Geist 321\& Lambin, 2002; Inostroza et al., 2010).

322 Both urban growth and population increase by the end of the $20^{\text {th }}$ century may have been 323strongly influenced by the construction of new highways, especially the BR-101 highway, which 324provided better and faster access to NCSP (Carmo et al., 2012; Cunha, 2003; Comitê de Bacias 
325Hidrográficas do Litoral Norte, 2016). In coastal zones, the presence of seaports has been a 326historically important driver of city development, influencing land use change both directly and 327indirectly, especially by increasing urban and industrial uses (Cunha, 2003; Felsenstein, Lichter, 328\& Ashbel, 2014). On the NCSP, the São Sebastião and Ubatuba Ports were likely a key driver for 329development, since their emergence as villages during the first half of $17^{\text {th }}$ century. The presence 330of the São Sebastião Port has in turn brought oil and gas companies to the same municipality 331(Cunha, 2003; Teixeira, 2013), and during the early $21^{\text {st }}$ century, the discovery of a new offshore 332oil and gas deposit in 2003 (pre-salt) and the construction of the Natural Gas Treatment Station 333of Caraguatatuba in 2007 increased investments in infrastructure and transportation projects 334linked with the energy industrial sector. Based on this timing, we can suggest accessibility 335improvements and the development of the oil and gas sector as two of the main drivers of the fast 336urban expansion and intensification observed from 1985 and 2015, especially in São Sebastião 337and Caraguatatuba municipalities. Landscape accessibility, considering terrestrial and marine 338transportation of people and goods, is known to be an important driver of landscape change 339influencing migration, rural depopulation, and the labor market, frequently resulting in rural 340abandonment and urban expansion (Antrop, 2005; Bürgi et al., 2017). Technological drivers of 341land use change in coastal zones have been confirmed for other countries; port construction and 342expansion in Israel (Felsenstein et al., 2014), accessibility improvements in coastal cities in 343Japan, Turkey, China and Brazil (Elmqvist et al., 2013), and the development of the energy 344sector and the presence of industries in Italy (Montanari, Londei, \& Staniscia, 2014), all leading 345to rural abandonment and urban expansion.

346 Tourism linked to coastal and marine activities is the most important component of the 347economy in the region, also demanding investments in infrastructure development, accessibility, 
348and the construction sector (CBHLN, 2016; IBGE, 2010). NCSP hosts more than 2,000 touristic 349establishments (i.e. hotels and restaurants), and the population frequently triples in number 350during the high season (CBHLN, 2016; FSEAD, 2016). Secondary residences within private 351condominiums are a frequent tourist accommodation in the NCSP, and the annual rate of 352increase in built-up areas was higher than the annual rate of population growth (1.6\%, FSEAD, 3532016), for both dense urban (3.6\%) and peri-urban (1.9\%) increases, which may be explained by 354the expansion of tourism infrastructure and vacation homes. It is thus reasonable to assume that 355the tourism sector and the housing market are also strong drivers of the urban expansion 356quantified by us in the NCSP, especially in the Ilhabela municipality, which has had the highest 357percent growth in dense urban settlements, and that these activities are likely to continue 358influencing land use changes and land governance. The role of tourism on land cover change has 359also been shown for other coastal and touristic regions (Corona, Galicia, Palacio-Prieto, Bürgi, \& 360Hersperger, 2016; Elmqvist et al., 2013),

361 The complex interaction between economic and political drivers has been discussed 362before as the main reason behind land use change in coastal and touristic zones, especially 363regarding changes from agricultural use and forest cover to urban and industrial areas. The 364presence of ports and industries, as well as other urban and touristic services, provides several 365job opportunities and make coastal cities an attractive place for living, resulting in fast urban 366expansion and intensification from migration (Elmqvist et al., 2013; Montanari et al., 2014). In 367the NCSP, these processes are particularly well illustrated by the land abandonment quantified 368by us from 1985 to 1990, followed by urban sprawl and urban intensification due to peri-urban369expansion between 1990-1995 and 2005-2015, with dense urban increase during the entire 370period. Regarding land abandonment in the NCSP, studies suggest that the conversion from rural 
371to urban happened mostly prior to our studied period, between 1960 and 1980 (Campos, 2000; 372Carmo et al., 2012; Silva, 1975). However, our results shown a continuing trend of conversion 373from rural to urban uses between 1985 and 2015, which is also reported by the Brazilian Rural 374Census data (LUPA 1995, 2007), where agricultural areas decreased in almost all NC 375municipalities, from $20.5 \%$ (1995) to $13.9 \%$ (2007) of the NCSP territory.

376 Conversely, part of the observed peri-urban growth between 1985 and 2015 (26.6\% of 377FTS) can be also related to both transitions to mixed land uses and an increase in rural villages. 378We could not discriminate between these two sources of peri-urban increases due to the spatial 379resolution of our source images, and their relative contribution to LULCC in the region should be 380better studied in the future. An increase in rural villages can be a consequence of land use 381planning policies aiming to improve landscape sustainability provided by traditional populations 382and small farmers. Protected areas such as Indigenous Territories and Natural Heritage Areas 383were created during the late 1980's and early 1990's aiming to protect these population's 384territories. The Serra do Mar State Park management plan has delimited the Historical-Cultural 385and Archaeological Zone (São Paulo, 2006), allowing native people settlements to persist inside 386park areas, and Federal Decree ${ }^{\circ} 6040$ (National Policy for Sustainable Development of the 387Traditional Communities and Populations) has defined and protected traditional populations as a 388Brazilian Heritage, such as the Caiçara, Indigenous and Quilombola populations (Brasil 2007). 389The presence of local stakeholders, non-profit organizations and non-governmental organizations 390has been shown to be essential for developing sustainable cities, especially in regions with land 391use conflicts such as coastal and touristic regions (Elmqvist et al., 2013; Morgado, Gomes \& 392Costa, 2014).

393 
394 4.2. The effect of policies on forest persistence, afforestation, deforestation and 395 disturbance

$396 \quad$ Mature forest loss and disturbance within park limits $\left(100 \mathrm{~km}^{2}\right)$ were a consequence of 397settlement intensification and sprawl outside and at the edge of the parks, likely because the 398footprint of urban expansion usually overcomes political borders (Antrop, 2005; Elmqvist et al., 3992013). On the other hand, more than 95\% of the state parks are still covered by mature forest 400(84.3\%). As strictly protected areas, we suggest that the legislation instituting the three state 401parks has been an effective instrument for ensuring forest persistence and afforestation, even if a 402few deforested areas have been observed. The current policies for parks and other Brazilian 403protected areas are defined by the 2000 Brazilian Protected Areas federal legislation. This 404legislation forbids any human settlement inside Brazilian parks, and establishes that parks are 405created mainly for nature conservation, research and tourism. The federal legislation is usually 406complemented by the management plan of each protected area; the management plan of Serra do 407Mar State park (2006) establishes the strategic spatial plan for park management, defining 408different zones (including protective buffer zones around park limits), and its allowed uses. 409Considering this, we suggest that both instruments have been equally important for the observed 410forest persistence and afforestation process, and we recommend more effort by park managers in 411elaborating and implementing the required management plans. Several protected areas are 412created without having a management plan in place, or with plans that not integrated with other 413local land use plans, making it difficult to promote nature conservation strategies that are aligned 414with the economic and social life of neighbouring communities (Brasil, 2000; Freitas Lima; 415Ranieri, 2018). 
416 Although urban expansion has mainly removed natural forest areas in the NCSP, 417regenerating forest have remained as a dominant land cover class outside parks limits, covering 418more than $40 \%$ of these areas and concentrating mostly in the foothills behind the coastal plains. 419In agreement with our data, a joint report by the S.O.S Mata Atlântica Foundation and the 420National Institute for Space Research (F.S.O.S \& I.N.P.E, 2016) has also quantified a decline in 421deforestation rates and increase in regenerating areas for the entirety of the Atlantic Forest in São 422Paulo, between 2000 and 2016. For the NCSP, we suggest that the legal instruments for land use 423planning and forest conservation published during the late 1990’s and early 2000's are likely to 424be the main drivers of forest persistence and afforestation outside park boundaries quantified 425between 2000 and 2010. Internationally, the recognition of the Atlantic Forest as a Biosphere 426Reserve (UNESCO, 1991) strongly influenced Brazilian authorities to improve protection efforts 427for the Atlantic Forest; the Federal Law of Environmental Crimes (Law n 9605 of 1998) and the 4282006 Federal Law for Protection of the Atlantic Forest Biome criminalizes deforestation and 429other environmental transgressions in this biome, even outside parks. This law was also the first 430to protect secondary stage (regenerating) forests against any harvesting or exploring activities, 431and we suggest that it may have influenced the afforestation process and the persistence of 432regenerating forest we observed in the NCSP. Also, in terms of strategic spatial planning, the 433Ecological-Economic Zoning (State Decree 49.215/2004), led by the São Paulo State 434Government, has probably been an import driver of forest persistence and afforestation 435quantified after 2005, as this legislation determined standards and policies for land use in the 436NCSP, and delimited zones where forest cover maintenance is enforced, especially at foothills 437and riparian forests, in agreement with the Brazilian Forestry Code (1965, 2012). 
438 The topography itself also certainly plays a role in forest conservation on the NCSP. Most

439forested areas mapped by us were located in steep slope areas, and the parks mostly protect 440scarps and high elevation areas, while dense urban settlements mostly cover the flat lowlands 441near the coastline. Topography has been broadly discussed as a driver of forest persistence and 442afforestation in different landscapes and countries, as a result of human preferences of settling in 443flat areas (Ab’Sáber, 2007; Pazúr \& Bolliger, 2017; Schneeberger, Bürgi, Hersperger, \& Ewald, 4442007; Silva et al., 2016).

445

446 4.3. Consequences of the dichotomy between fast urban growth and forest persistence

447 Presently, the NCSP shows high rates of human settlement expansion and a continuous 448decrease in rural areas, while still maintaining more than $80 \%$ of its territory protected by the 449three state parks and by general environmental laws. This trajectory of land use and land cover 450change between 1985 and 2015 has resulted in loss of landscape heterogeneity and 451multifunctionality, resulting on a strong dichotomy between urban use and forest cover. 452Population growth rates have declined since 2000, but are still among the highest in the state 453(FSEADE, 2016; Instituto Brasileiro de Geografia e Estatística, 2010). Rosemback et al. (2017) 454predicts that the number of primary residences (i.e. main homes of local residents, excluding 455tourism-oriented secondary residences) in the in NCSP will increase by $48 \%$ by 2030, due to 456changes in demographic structure. The authors also conjecture that this growth will be mostly 457located in peri-urban areas, since the dense urban areas are already mainly occupied by tourism 458infrastructure, and the urban land available for new development is very expensive.

459 Outside park limits, dense urban and peri-urban areas occupy $160 \mathrm{~km}^{2}$ (30\%), forests 460occupy c.a. 50\% and all other land cover types occupy less than $15 \%\left(80 \mathrm{~km}^{2}\right)$. If our observed 
461average annual rate of urban and peri-urban expansion remains unchanged (business-as usual 462scenario), we can expect that urban areas will increase by $65.7 \mathrm{~km}^{2}$ and peri-urban areas will 463increase by $11.9 \mathrm{~km}^{2}$, for a total of $77.6 \mathrm{~km}^{2}$ of built-up areas by 2030 . Therefore, for this growth 464to be accommodated almost all remaining non-protected lands will need to be converted to urban 465and peri-urban uses by 2030. This assumption is not unreasonable, as several authors have 466predicted that rates of urban growth will continue to increase rapidly in many parts of the world, 467considering both sprawl and intensification, especially the peri-urban areas of developing 468countries and coastal zones surrounded by biodiversity hotspots (Ellis \& Ramankutty, 2008; 469Elmqvist et al., 2013; Verburg et al., 2015). The UN (2009) has also predicted that urban 470population in South American cities will increase by 34\% until 2050, and Inostroza et al. (2010) 471have predicted that the urban core area of major cities in South America will double by 2035, 472assuming that rates of change continue at their current levels.

473 These expected land cover changes are likely to result in negative effects that go beyond 474a land use planning crisis. The increase in peri-urban use quantified by us between 1990-1995 475and 2005-2015 is likely associated to informal settlement leading to disadvantaged 476neighbourhoods (e. g. “slums”), which suffer from a combination of economic, health, and 477environmental issues resulting from unplanned urban sprawl and expansion of urban limits. This 478suburbanization phenomena has been described as a frequent consequence of the fast urban 479sprawl in several Latin America cities and developing countries in general, usually led by 480economic drivers (Elmqvst 2013, Inostroza et al., 2010). In Latin America, per capita land 481consumption has increased for the richer economic classes in urban areas, increasing land prices 482and driving the poorest segments of the population away from urban centres and facilities 483(Inostroza et al., 2010). 
484 Furthermore, the loss of traditional rural landscapes will negatively impact quality of life 485in the region. Traditional uses promote sustainable landscapes (Antrop 2005), and the 486replacement of rural areas can result in loss of landscape functionality and diversity and critically 487impact food security, also changing the complex relationship between people and the landscape 488(Antrop, 2005; Bürgi, Verburg, et al., 2017; De Groot, 2006; McNeely \& Scherr, 2009; 489Nassauer, 1995; Tuan, 1983). Traditional peoples and small farmers still present in the NCSP are 490currently the main drivers of landscape multifunctionality maintenance. However, most of the 491territories occupied by these communities are not properly delimited by legal instruments,and if 492the observed rates of urbanization persist, traditional peoples and landscape multifunctionality 493will be both under severe threat.

\section{Conclusions}

495 Our work provides a detailed characterization of urban expansion and sprawl, and 496advances our understanding of the main drivers of land use and cover change in the Northern 497Coast of São Paulo state. These results are an important subsidy for future land use planning and 498landscape management, as we show that available land for human settlement has been decreasing 499steadily in the studied region, especially since c.a. $80 \%$ of the entire region is still comprised by 500park areas under very strict land use regulation.

501 Our observed results and the supporting literature show that economic policies, including 502the expansion and improvement of road accessibility and the presence of large industrial 503enterprises were important drivers of population growth until now, resulting in dense urban and 504peril-urban expansion. Another important driver is the continued expansion of the tourism and 505housing markets, which also influence migration and increases the demand for both primary and 506secondary residences, further driving the expansion of built-up areas paired with rural use 
507decline. Current economic and demographic observations suggest that the same rates and 508trajectories of past land changes can be expected to continue in the future, as there has been no 509significant changes in land use planning policies and/or efforts to create a more diverse and 510multifunctional landscape for the NCSP region. If this expectation is proven true, urban and 511peri-urban expansion will replace all other land uses and cover types outside park areas by 2030, 512including unprotected forest areas, native and traditional people's territories and the remaining 513rural uses. Considering that the Northern Coast of São Paulo state still shows high rates of 514population growth that demand the construction of new primary residences, and that there are 515large scale logistic enterprises such as road and port expansion and increases in oil exploration 516planned for the near future, the region may be fast approaching a land use planning and 517management crisis.

518 To authorities and planners, we thus suggest more effort in establishing long-term and 519sustainable housing and development programs, instead of focusing solely on business and 520industry growth. For instance, we suggest the development of a tiered municipal urban service 521tax regime that taxes more highly properties corresponding to industrial uses, high value 522accommodations, hotels and other enterprises that more heavily consume landscape space and 523ecosystem services, while providing tax incentives for primary residence uses and for the 524implementation of sustainable uses and landscape diversification practices in private land.

525 The role of local actors and institutions has been essential for maintaining landscape 526multifunctionality and protecting traditional rural landscapes, promoting sustainable interactions 527between forest cover conservation and diverse agricultural uses, but more concrete actions are 528needed to protect traditional rural landscapes and promote landscape multifunctionality. We urge 529government agencies and decision-makers involved in the planning and administration of the 
530NCSP to review current policies and regulations for land use both within and outside parks to 531make them more inclusive, with strong participation from all stakeholders, otherwise these 532alternative uses will be lost within a few decades and the progressive urban encroachment will 533start to strongly threaten the effectiveness of existing protected areas. The developing of more 534participatory management instruments and regulations that effectively engage public 535administrators, traditional communities, small farmers, representatives of the tourism sector and 536other important stakeholders in the land use planning process may improve the success of 537strategic spatial planning and governance, developing more sustainable and multifunctional 538landscapes in the region. We also hope our results may help guide landscape management and 539conservation policies in similar coastal regions throughout the world. 


\section{References}

541

542

543

544

545

546

547

548

549

550

551

552

553

554

555

556

557

558

559

560

561

562

563

564

565

566

567

568

569

570

571

572

573

574

575

576

577

578

579

580

581

582

583

584

585
1. Ab’Sáber, A. (1986). O tombamento da Serra do Mar no Estado de São Paulo. Revista Do Patrimônio Histórico E Artístico Nacional, 21, 7-20. Retrieved from http://portal.iphan.gov.br/uploads/publicacao/RevPat21_m.pdf

2. Ab’Sáber, A. (2007). Os domínios da natureza no Brasil: Potencialidades Paisagísticas $\left(4^{\circ}\right)$. São Paulo: Ateliê Editorial.

3. Almeida, F. F. . de;, \& Carneiro, C. dal R. (1998). Origem e evolução da Serra do Mar. Evista Brasileira de Geociências, 28(2), 135-150.

4. Antrop, M. (2000). Background concept for integrated landscape analysis. Agriculture, Ecosystems and Environment, 77(July 1999), 17-28.

5. Antrop, M. (2005). Why landscapes of the past are important for the future. Landscape and Urban Planning, 70(1-2), 21-34. https://doi.org/10.1016/j.landurbplan.2003.10.002

6. Blaschke, T. (2010). Object based image analysis for remote sensing. ISPRS Journal of Photogrammetry and Remote Sensing. Journal of Photogrammetry and Remote Sensing, 65(1), 2-16. Retrieved from https://doi.org/10.1016/j.isprsjprs.2009.06.004

7. Blaschke, T., Hay, G.J., Kelly, M., Lang, S., Hofmann, P., Addink, E., Feitosa, R.Q., Meer, F.V.D., Werff, H.V.D., Coillie, F.V. (2014). Geographic object-based image analysis - towards a new paradigm. ISPRS J. Photogramm. Remote Sensing. 87, 180191.

8. Brasil. (2000). Lei ${ }^{\circ} 9.985$, de 18 de julho de 2000, institui o Sistema Nacional de Unidades de Concervação da Natureza. Brasil. Retrieved from http://www.planalto.gov.br/ccivil_03/LEIS/L9985.htm

9. Breiman, L. (2001). Randomforest2001. Machine Learning, 45(1), 5-32. https://doi.org/10.1017/CBO9781107415324.004

10. Bunting, P., \& Clewley, D. (2013). The Remote Sensing and GIS Software Library . Computers and Geosciences, 60, 216-226.

11. Bürgi, M., Bieling, C., von Hackwitz, K., Kizos, T., Lieskovský, J., Martín, M. G., ... Printsmann, A. (2017). Processes and driving forces in changing cultural landscapes across Europe. Landscape Ecology, 32(11), 2097-2112. https://doi.org/10.1007/s10980017-0513-z

12. Bürgi, M., Hersperger, A. M., \& Schneeberger, N. (2004). Driving forces of landscape change - current and new directions. Landscape Ecology, 19(8), 857-868. https://doi.org/ 10.1007/s10980-004-0245-8

13. Bürgi, M., Verburg, P. H., Kuemmerle, T., \& Plieninger, T. (2017). Analyzing dynamics and values of cultural landscapes. Landscape Ecology, 32(11), 2077-2081. https://doi.org/10.1007/s10980-017-0573-0

14. Campos, J. F. de. (2000). Santo Antônio de Caraguatatuba: memórias e tradição de um povo. Caraguatatuba: FUNDACC.

15. Carmo, R. L. do, Marques, C., \& Miranda, Z. A. I. de. (2012). Dinâmica Demográfica Economia e Ambiente na Zona Costeira de São Paulo. Textos Nepo 63, 63, 1-111. Retrieved from http://www.nepo.unicamp.br/textos/publicacoes/textos_nepo/textos_nepo_63.pdf

16. Comitê de Bacias Hidrográficas do Litoral Norte (CBHLN). (2014). Relatório de Situação dos Recursos Hídricos do Litoral Norte Ano 2014 - Dados 2013, 42.

17. Comitê de Bacias Hidrográficas do Litoral Norte (CBHLN). (2016). Plano de Bacias 
586

587

588

589

590

591

592

593

594

595

596

597

598

599

600

601

602

603

604

605

606

607

608

609

610

611

612

613

614

615

616

617

618

619

620

621

622

623

624

625

626

627

628

629

630

631

Hidrográficas do Litoral Norte, (Watershed Manage Plan - Northern Coast of São Paulo) 2016

18. Congalton, R. G. (1991). A Review of Assessing the Accuracy of Classification of Remotely Sensed Data A Review of Assessing the Accuracy of Classifications of Remotely Sensed Data. Remote Sensing of Environment, 4257(September), 34-46. https://doi.org/10.1016/0034-4257(91)90048-B

19. Corona, R. ., Galicia, L. ., Palacio-Prieto, J. L. ., Bürgi, M. ., \& Hersperger, A. . (2016). Local deforestation patterns and driving forces in a tropical dry forest in two municipalities of southern Oaxaca, Mexico (1985-2006)) [Patrones y conductores de la deforestación a escala local de la selva baja caducifolia en dos municipios a sur de Oaxac. Investigaciones Geograficas, 2016(91), 86-104. https://doi.org/10.14350/rig.50918

20. Cunha, Í. (2003). Conflito ambiental em águas costeiras: relação porto - cidade no Canal de São Sebastião. Ambiente \& Sociedade, 6(2), 83-98. https://doi.org/10.1590/S1414753X2003000300006

21. De Groot, R. (2006). Function-analysis and valuation as a tool to assess land use conflicts in planning for sustainable, multi-functional landscapes. Landscape and Urban Planning, 75(3-4), 175-186. https://doi.org/10.1016/j.landurbplan.2005.02.016

22. Dean, W. (1996). A ferro e fogo: a história e a devastação da Mata Atlântica brasileira (1st ed.). São Paulo: Cia das Letras.

23. Ellis, E. C., \& Ramankutty, N. (2008). Putting people in the map: Anthropogenic biomes of the world. Frontiers in Ecology and the Environment, 6(8), 439-447. https://doi.org/10.1890/070062

24. Elmqvist, T., Fragkias, M., Goodness, J., Güneralp, B., Marcotullio, P. J., McDonald, R. I., ... Tidball, K. (2013). Urbanization, Biodiversity and Ecosystem Services: Challenges and Opportunities. (Springer, Ed.), Urbanization, Biodiversity and Ecosystem Services: Challenges and Opportunities: A Global Assessment. Dordrecht. https://doi.org/10.1007/978-94-007-7088-1 33

25. Freitas Lima, E. A. C.; Ranieri, V. E. L. (2018). Land use planning around protected areas: case studies in four state parks in the Atlantic Forest region of southeastern Brazil. Land Use Policy, 71.

26. Felsenstein, D., Lichter, M., \& Ashbel, E. (2014). Coastal congestion: Simulating port expansion and land use change under zero-sum conditions. Ocean and Coastal Management, 101(PB), 89-101. https://doi.org/10.1016/j.ocecoaman.2014.08.001

27. FSEADE. (2016). Informações dos Municípios Paulistas. Retrieved from http://www.imp.seade.gov.br/frontend/\#/tabelas

28. Fundação SOS Mata Atlântica; Instituto Nacional de Pesquisas Espaciais (F.S.O.S \& I.N.P.E). (2016). ATLAS DOS REMANESCENTES FLORESTAIS DA MATA ATLÂNTICA PERÍODO 2014-2015. Fundação SOS Mata Atlântica e Instituto de Pesquisas Espaciais.

29. Geist, H. J., \& Lambin, E. F. (2002). Proximate Causes and Underlying Driving Forces of Tropical Deforestation. BioScience, 52(2), 143. https://doi.org/10.1641/00063568(2002)052[0143:PCAUDF]2.0.CO;2

30. Hijmans, R. J., van Etten, J., Cheng, J., Mattiuzzi, M., Sumner, M., Greenberg, J. A., ... Shortridge, A. (2016). Package "raster":geographic data analysis and modeling. In: R Package Version 2.5-2. Retrieved from https://cran.r-project.org/package=raster

31. Inostroza, L., Baur, R., Csaplovics, E., (2010). Urban Sprawl and Fragmentation in 
632

633

634

635

636

637

638

639

640

641

642

643

644

645

646

647

648

649

650

651

652

653

654

655

656

657

658

659

660

661

662

663

664

665

666

667

668

669

670

671

672

673

674

675

676

677

Latin America: A Comparison with European Cities. The Myth of the Diffuse Latin American City. Lincoln Institute of Land Policy Working Paper. http://www.urbansprawlproject.com/planos/Inostroza et al 2010.pdf

32. Instituto Brasileiro de Geografia e Estatística (IBGE). (1970,1980, 1991, 2000, 2010). Censo 1970,1980, 1991, 2000, 2010. Retrieved March 7, 2016, from http://censo2010.ibge.gov.br/resultados.html

33. Kennedy, R. E., Yang, Z., \& Cohen, W. B. (2010). Detecting trends in forest disturbance and recovery using yearly Landsat time series: 1 . LandTrendr - Temporal segmentation algorithms. Remote Sensing of Environment, 114(12), 2897-2910. https://doi.org/10.1016/j.rse.2010.07.008

34. Maricato E (2003) Metrópole, legislação e desigualdade. Estudos Avançados (São Paulo, IEA-USP) 17: 151-166

35. McNeely, J. A., \& Scherr, S. J. (2009). Ecoagricultura : alimentação do mundo e biodiversidade. São Paulo: Editora Senac.

36. Mittermeier, R. A., Robles-Gil, P., Hoffmann, M., Pilgrim, J. D., Brooks, T. B., Mittermeier, C. G., ... Fonseca, G. A. z. (2004). Hotspots Revisited: Earths Biologically Richest and Most Endangered Ecoregions. Mexico City: CEMEX.

37. Montanari, A., Londei, A., \& Staniscia, B. (2014). Can we interpret the evolution of coastal land use conflicts? Using Artificial Neural Networks to model the effects of alternative development policies. Ocean and Coastal Management, 101(PB), 114-122. https://doi.org/10.1016/j.ocecoaman.2014.09.021

38. Morgado, P., Gomes, E., \& Costa, N. (2014). Competing visions? Simulating alternative coastal futures using a GIS-ANN web application. Ocean and Coastal Management, 101(PB), 79-88. https://doi.org/10.1016/j.ocecoaman.2014.09.022

39. Nassauer, J. I. Culture and changing landscape structure. Landscape Ecology, v. 10, n. 4, p. 229-237, 1995

40. Pazúr, R., \& Bolliger, J. (2017). Land changes in Slovakia: Past processes and future directions. Applied Geography, 85, 163-175. https://doi.org/10.1016/j.apgeog.2017.05.009

41. Pedregosa, F., Varoquaux, G., Gramfort, A., Michel, V., Thirion, B., Grisel, O., ... Duchesnay, É. (2012). Scikit-learn: Machine Learning in Python. Journal of Machine Learning Research, 12, 2825-2830. https://doi.org/10.1007/s13398-014-0173-7.2

42. . https://doi.org/10.1016/j.landusepol.2016.04.040

43. Ribeiro, M. C., Metzger, J. P., Camargo Martensen, A., Ponzoni, F. J., \& Hirota, M. M. (2009). The Brazilian Atlantic Forest: How much is left, and how is the remaining forest distributed? Implications for conservation. Biological Conservation, 142, 1141-1153. https://doi.org/10.1016/j.biocon.2009.02.021

44. Rosemback, R. G., Rangel Rigotti, J. I., Da Fonseca Feitosa, F., Vieira Monteiro, A. M., Rosemback, R. G., Rigotti, J. I. R., ... Monteiro, A. M. V. (2017). Demografia, planejamento territorial e a questão habitacional: prognóstico da situação habitacional do Litoral Norte Paulista. Revista Brasileira de Estudos de População, 34(2), 1. https://doi.org/10.20947/S0102-3098a0005

45. Rossi, M., \& Queiroz Neto, J. P. (2001). Os solos como indicadores das relações entre sedimentos continentais e marinhos na planície costeira: Rio Guaratuba (SP). Revista Brasileira de Ciência Do Solo, 25(1), 113-120. https://doi.org/10.1590/S010006832001000100012 
678

679

680

681

682

683

684

685

686

687

688

689

690

691

692

693

694

695

696

697

698

699

700

701

702

703

704

705

706
46. São Paulo. (1977). Decreto Estadual nº 10.251 de 30 de agosto de 1977. Cria o Parque Estadual da Serra do Mar e dá providências correlatas. Retrieved from http://www.al.sp.gov.br/repositorio/legislacao/decreto/1977/decreto-1025130.08.1977.html

47. São Paulo. (1995). Levantamento Censitário das Unidades de Produção Agropecuária (LUPA) - Brazilian Rural Census data

48. São Paulo. (2006). Parque Estadual da Serra do Mar - Plano de Manejo. São Paulo: Secretaria do Meio Ambiente /Instituto Florestal.

49. São Paulo. (2007). Levantamento Censitário das Unidades de Produção Agropecuária (LUPA) Brazilian Rural Census data

50. São Paulo. (2015). Plano de Manejo do Parque Estadual Ilhabela. Ilhabela.

51. Schneeberger, N., Bürgi, M., Hersperger, A. M., \& Ewald, K. C. (2007). Driving forces and rates of landscape change as a promising combination for landscape change research - An application on the northern fringe of the Swiss Alps. Land Use Policy, 24(2), 349361. https://doi.org/10.1016/j.landusepol.2006.04.003

52. Silva. (1975). O litoral norte do estado de São Paulo: formação de uma região periférica /. São Paulo : Instituto de Geografia, Universidade de São Paulo,.

53. Silva, R. F. B. da., Batistella, M., \& Moran, E. F. (2016). Drivers of land change: Human-environment interactions and the Atlantic forest transition in the Paraíba Valley, Brazil. Land Use Policy, 58, 133-144. https://doi.org/10.1016/j.landusepol.2016.07.021

54. Teixeira, L. (2013). Megaprojetos no litoral norte paulista: o papel dos grandes empreendimentos de infraestrutura na transformação regional. 2013. Universidade Estadual de Campinas.

55. Tuan, Y. F. (1983). Espaço e lugar: a perspectiva da experiência. São Paulo: DIFE.

56. Verburg, P. H., Crossman, N., Ellis, E. C., Heinimann, A., Hostert, P., Mertz, O., ... Zhen, L. (2015). Land system science and sustainable development of the earth system: A global land project perspective. Anthropocene, 12, 29-41. https://doi.org/10.1016/j.ancene.2015.09.004 
707List of tables

708Table 1 - Land use and land cover classes used for mapping land cover changes in the Northern 709Coast of São Paulo State, Brazil, between 1985 and 2015, using Landsat historical data.

710Table 2. Kappa index of agreement and omission and commission errors for each LULC class 711from 2000, 2010 e 2015, after manual correction. 
712Table 1 - Land use and land cover classes used for mapping land cover changes in the Northern 713Coast of São Paulo State, Brazil, between 1985 and 2015, using Landsat historical data.

\begin{tabular}{l|l}
\hline Land use / land cover class & Description \\
\hline Mature forest & $\begin{array}{l}\text { Dense forest characterized by an advanced successional stage } \\
\text { comprised mainly by primary forest, or occasional old-growth } \\
\text { secondary forest. }\end{array}$ \\
\hline Regenerating forest & $\begin{array}{l}\text { Less dense forest, early to medium successional stages, mostly } \\
\text { comprised by regenerating secondary forest. }\end{array}$ \\
\hline Non-forest vegetation & $\begin{array}{l}\text { Native or exotic vegetation including pastures, grasslands and } \\
\text { agriculture. }\end{array}$ \\
\hline Bare soil and rock & $\begin{array}{l}\text { Exposed soil or rock surfaces lacking vegetation and buildings } \\
\text { and including sandy beaches and rocky shores. }\end{array}$ \\
\hline Peri-urban & $\begin{array}{l}\text { Mixed areas with lower population density and sparse } \\
\text { buildings, including a high diversity of rural uses, agroforestry, } \\
\text { and small forest fragments. }\end{array}$ \\
\hline Dense urban settlements & \begin{tabular}{l} 
Dense built-up areas, mostly urban. \\
\hline Water
\end{tabular} \\
\hline
\end{tabular}

714 
715Table 2. Kappa index of agreement and omission and commission errors for each LULC class 716from 2000, 2010 e 2015, after manual correction.

\begin{tabular}{l|c|c|c|c|c|l|l|l|l}
\hline \multirow{2}{*}{\multicolumn{1}{c}{ Classes }} & \multicolumn{3}{|c|}{ Kappa Index } & \multicolumn{3}{c|}{ Omission Error } & \multicolumn{3}{c}{ Commission Error } \\
\cline { 2 - 10 } & 2000 & 2010 & 2015 & 2000 & 2010 & 2015 & 2000 & 2010 & 2015 \\
\hline Non-forest vegetation & 0.85 & 0.91 & 0.94 & 0.15 & 0.07 & 0.05 & 0.13 & 0.07 & 0.05 \\
Peri-urban & 0.79 & 0.68 & 0.85 & 0.13 & 0.17 & 0.07 & 0.18 & 0.28 & 0.13 \\
Bare soil/rock & 0.83 & 0.97 & 0.93 & 0.00 & 0.03 & 0.09 & 0.15 & 0.03 & 0.06 \\
Dense urban settlements & 1.00 & 1.00 & 0.88 & 0.05 & 0.00 & 0.03 & 0.00 & 0.00 & 0.10 \\
Mature forest & 0.85 & 0.88 & 1.00 & 0.10 & 0.10 & 0.06 & 0.13 & 0.10 & 0.00 \\
Regenerating forest & 0.81 & 0.72 & 0.93 & 0.26 & 0.31 & 0.08 & 0.15 & 0.23 & 0.06 \\
\hline
\end{tabular}

717

718 


\section{List of figures}

721Figure 1. A) Map of Brazil showing the location of São Paulo State (SP). B) Northern Coast of 722São Paulo State showing the location of state parks, main highways, oil and gas infrastructure, 723major ports and airports, and urban and peri-urban census sectors.

725Figure 2. Main land use and land cover change processes observed between 1985 and 2015. A) 726non-forest vegetation, peri-urban and dense urban settlement increase; B) Forest dynamics: 727afforestation, deforestation, forest disturbance (primary to secondary forest), forest persistence. 728C) Digital Elevation Model (ALOS World3D).

730Figure 3. Land use and land cover change trajectories for the areas of the Northern Coast of São 731Paulo outside park limits: A) All conversion types; B) land use / cover conversion to dense urban 732settlements and peri-urban areas. RF = Regenerating forest; MF = Mature forest; DU = Dense 733urban settlement; PU = Peri-urban; NF = Non-forest vegetation

734Figure 4. Peri-urban and dense urban settlement dynamics: example from the central region of 735Ubatuba municipality. Land abandonment = peri-urban conversion to non-forest vegetation and 736regenerating forest; Peri-urban persistence = peri-urban maintenance during the time step; Peri737urban increase $=$ conversion from any cover class to peri-urban; Dense urban increase = 738conversion from any cover class to dense urban; Urban intensification $=$ conversion from peri739urban to dense urban, Urban persistence = dense urban maintenance during the time step. 
740List of appendices

741A) Methods: Scripts for processing on “RSGISlib” free algorithms library, in Python language:

742

743

744

745

A.i) Segmentation

746

747B) Results

748

749

750

751

A.ii) Random Forest Classification

752State

B.i) Land use and land cover maps

B.ii) Land use and cover characterization inside and outside state parks

753

754

B.iii) Transitional matrix of land use and land cover change Northern Coast of São Paulo 